\title{
Effect of dietary supplementation of sodium acetate and calcium butyrate on milk fat synthesis in lactating dairy cows
}

\author{
N. Urrutia, ${ }^{1}$ R. Bomberger, ${ }^{2}$ C. Matamoros, ${ }^{2}$ and K. J. Harvatine ${ }^{2 *}$ \\ ${ }^{1}$ Instituto de Investigaciones Agropecuarias, INIA Remehue, Osorno, Los Lagos 5290000, Chile \\ ${ }^{2}$ Department of Animal Science, The Pennsylvania State University, University Park 16802
}

\section{ABSTRACT}

Acetate is a major source of energy and substrate for milk fat synthesis in the dairy cow. We recently reported a linear increase in milk fat yield and greater than a $30 \%$ net apparent transfer of acetate to milk fat with ruminal infusion of neutralized acetate. Additionally, ruminal acetate infusion linearly increases plasma $\beta$-hydroxybutyrate. The objective of the current study was to investigate the ability of acetate and butyrate fed in a diet to increase milk fat synthesis. Twelve multiparous lactating Holstein cows were randomly assigned to treatments in a $3 \times 3$ Latin square design with 14 -d periods that included a 7 - $\mathrm{d}$ washout followed by $7 \mathrm{~d}$ of treatment. Cows were fed ad libitum a basal diet with a low risk for biohydrogenation-induced milk fat depression, and treatments were mixed into the basal diet. Treatments were $3.2 \% \mathrm{NaHCO}_{3}$ (control), $2.9 \%$ sodium acetate, and $2.5 \%$ calcium butyrate (carbon equivalent to acetate treatment) as a percent of diet dry matter. Feeding sodium acetate increased dry matter intake by $2.7 \mathrm{~kg}$, had no effect on milk yield, and increased milk fat yield by $90 \mathrm{~g} / \mathrm{d}$ and concentration by 0.2 percentage units, compared with control. Calcium butyrate decreased dry matter intake by $2.6 \mathrm{~kg} / \mathrm{d}$, milk yield by $1.65 \mathrm{~kg} / \mathrm{d}$, and milk fat yield by $60 \mathrm{~g} / \mathrm{d}$, compared with control. Sodium acetate increased concentration and yield of 16 carbon mixed source fatty acids (FA) and myristic acid, while decreasing the concentration of preformed FA, compared with control. Calcium butyrate had no effect on concentration of milk FA by source, but increased concentration of trans-10 C18:1 in milk by $18 \%$, indicating a shift in rumen biohydrogenation pathways. Our data demonstrate that milk fat yield and concentration can be increased by feeding sodium acetate at $2.9 \%$ of diet dry matter, but not by feeding calcium butyrate at an equivalent carbon mass.

Received November 20, 2018.

Accepted February 15, 2019.

*Corresponding author: kjh182@psu.edu
Key words: acetate, butyrate, dairy cow, milk fat synthesis

\section{INTRODUCTION}

Milk fat production is important to the dairy industry because of its high market value and the properties milk fat imparts to dairy products. However, of all milk components, milk fat is the most variable and is highly influenced by diet nutrient composition (Palmquist et al., 1993). Therefore, dietary strategies aiming to increase milk fat synthesis are of special interest.

Milk fatty acids (FA) originate either from de novo synthesis in the mammary gland or from uptake of plasma FA from dietary absorption or endogenous reserves (preformed FA). Acetate is the predominant substrate for de novo FA synthesis in the dairy cow because it serves as a 2-carbon donor for synthesis of malonyl$\mathrm{CoA}$ and for NADPH synthesis through the isocitrate pathway (Bauman et al., 1970; Ingle et al., 1973; Smith, 1983). Additionally, in the well-fed cow, acetate is the major VFA produced in the rumen and provides $45 \%$ of the energy arising from VFA metabolism (Baldwin and Smith, 1971; Bergman, 1990). Therefore, acetate is fundamental for meeting energy requirements and for milk fat synthesis in the dairy cow.

Studies examining the role of acetate supply on milk fat synthesis were mostly conducted over $30 \mathrm{yr}$ ago [1955 to 1978; summarized in Urrutia and Harvatine (2017b)]. A meta-analysis primarily based on these early studies reported that acetate infusions linearly increased milk fat yield and concentration (Maxin et al., 2011), but these studies were small and used lower producing cows $(14.3 \pm 3.2 \mathrm{~kg} / \mathrm{d})$ fed diets very different from contemporary rations, therefore limiting extrapolation.

We recently reported that ruminal infusion of acetate neutralized to $\mathrm{pH} 6$ increases milk fat yield (Urrutia and Harvatine, 2017a,b). Specifically, in a 4-d dose response study, acetate linearly increased milk fat concentration and quadratically increased milk fat yield, with milk fat yield increasing 100, 217, and $185 \mathrm{~g} / \mathrm{d}$ 
when providing 300,600 , and $900 \mathrm{~g} / \mathrm{d}$ of sodium acetate respectively, compared with a sodium chloride control (Urrutia and Harvatine, 2017b). Acetate infusion also increased plasma BHB linearly at a rate of $5 \%$ per mole of acetate, possibly through conversion of acetate to butyrate in the rumen and rumen wall, and subsequent conversion to BHB (Sutton et al., 2003). The BHB provides about half of the initial carbons to make the 4 carbon primer for de novo FA synthesis (Palmquist et al., 1969); therefore, it is possible that a portion of the increase in milk fat synthesis observed during rumen acetate infusions is due to increased plasma BHB. In the meta-analysis of Maxin et al. (2011), a greater milk fat response was observed for butyrate than acetate infusion; milk fat yield increased $127 \mathrm{~g} / \mathrm{d}$ (adjusted $\mathrm{R}^{2}=$ 0.68 ) and concentration increased $7.96 \mathrm{~g} / \mathrm{kg}$ for each $\mathrm{kg}$ of additional butyrate $(P<0.001, \mathrm{n}=6)$. These data support a role for butyrate in stimulation of milk fat synthesis, but also provide a mechanism for increased milk fat synthesis observed during rumen infusion of acetate. The objective of the current experiment was to investigate the ability of the milk fat precursors acetate and butyrate to increase milk fat synthesis when fed in a TMR.

\section{MATERIALS AND METHODS}

\section{Experimental Design and Treatments}

All experimental procedures were approved by the Pennsylvania State University Institutional Animal Care and Use Committee. Twelve multiparous lactating Holstein cows (183 \pm 45 DIM; $45 \pm 4.7 \mathrm{~kg}$ of milk/d) were randomly assigned to treatments in a $3 \times 3$ Latin square design with 14-d periods, which included a 7-d washout and 7-d treatment period. Cows were housed in a tiestall barn located at the Pennsylvania State University Dairy Production Research and Teaching Center.

Cows were fed once daily at $0800 \mathrm{~h}$ at approximately $110 \%$ of expected intake and refusals were recorded daily. Treatments were sodium bicarbonate control (3.2\% of diet DM), sodium acetate at $2.9 \%$ of diet DM (targeting $10 \mathrm{~mol}$ of acetate/d; NaAc; Food grade anhydrous sodium acetate, Kemin Industries Inc., Des Moines, IA), and calcium butyrate at $2.5 \%$ of diet DM (CaBu; Kemin Industries Inc.). The control was designed to provide equal moles of sodium as $\mathrm{NaAc}$, and $\mathrm{CaBu}$ was designed to provide the same mass of carbon as NaAc. The basal TMR was balanced to have a low risk for biohydrogenation-induced milk fat depression as it contained adequate NDF and few rumen-available
UFA sources (Table 1). The basal TMR was mixed in a Kuhn RC 250 mixer and the treatments were mixed into the basal TMR in portable mixer cart (Rissler TMR mixer 1050, Rissler, Mohnton, PA) before delivery.

\section{Feed Sampling and Analysis}

Forage and base diet DM concentration was determined weekly for diet adjustment and DMI determination $\left(72 \mathrm{~h}\right.$ in a forced-air oven at $\left.55^{\circ} \mathrm{C}\right)$. All individual feed ingredients were sampled by period and forages and a representative composite of the grains was analyzed for $\mathrm{CP}, \mathrm{NDF}$, and ADF by wet chemistry procedures as described by Rico et al. (2014). The composition of each TMR differed slightly due to the small differences in treatment inclusion rates. This approach was selected because the treatments are water soluble and were not expected to change the fermentability or physical fill of the diet.

\section{Milk Sampling and Analysis}

Cows were milked twice daily at 0600 and $1800 \mathrm{~h}$ and milk yield was determined by an integrated milk meter (AfiMilk; SAE Afikim, Israel) as described by Urrutia and Harvatine (2017b). Milk was sampled at both milkings the day before treatment feeding and on $\mathrm{d} 3,6$, and 7 of treatment feeding. Samples were composited within day and analyzed for milk fat and protein by FTIR and milk FA profile by GLC as described by Urrutia and Harvatine (2017a). Milk composition on d 6 and 7 of feeding was averaged within period.

\section{Blood Sampling and Analysis}

Blood samples were collected from a coccygeal vessel using potassium EDTA tubes (Greiner Bio-One North America Inc., Monroe, NC) at 0500 and $1700 \mathrm{~h}$ on the last day of treatments to represent a low intake and high intake period of the day, respectively. Blood was immediately placed on ice, centrifuged within $30 \mathrm{~min}$ at $1,300 \times g$ for $15 \mathrm{~min}$ at $4^{\circ} \mathrm{C}$, and plasma was harvested and stored at $-20^{\circ} \mathrm{C}$ until laboratory analysis. Plasma samples were analyzed for glucose [PGO Enzyme procedure no. P 7119, Sigma-Aldrich, St. Louis, MO (Raabo and Terkildsen, 1960)], nonesterified fatty acids [NEFA; Wako HR Series NEFA-HR kit, Wako Chemicals USA, Richmond, VA, as modified by Ballou et al. (2009)], BHB (procedure \#2440, Stanbio Laboratory, Boerne, TX), and BUN (procedure \#2050, Stanbio Laboratory). 
Table 1. Ingredient and nutrient composition of experimental diets comparing sodium acetate to sodium bicarbonate DCAD control and equivalent carbon mass of butyrate as calcium butyrate ${ }^{1}$

\begin{tabular}{|c|c|c|c|}
\hline \multirow[b]{2}{*}{ Item } & \multicolumn{3}{|c|}{ Treatment $^{2}$} \\
\hline & Control & $\mathrm{NaAc}^{3}$ & $\mathrm{CaBu}^{4}$ \\
\hline \multicolumn{4}{|l|}{ Ingredient, $\%$ of $\mathrm{DM}$} \\
\hline Corn silage & 35.9 & 36.0 & 36.2 \\
\hline Alfalfa haylage & 12.9 & 13.0 & 13.0 \\
\hline Cracked corn & 10.9 & 11.0 & 11.0 \\
\hline Canola meal & 10.5 & 10.6 & 10.6 \\
\hline Bakery byproduct & 4.68 & 4.70 & 4.72 \\
\hline Roasted soybeans & 4.68 & 4.70 & 4.72 \\
\hline Molasses & 4.68 & 4.70 & 4.72 \\
\hline Whole cottonseed & 4.29 & 4.30 & 4.32 \\
\hline Grass hay & 3.90 & 3.91 & 3.93 \\
\hline Ground corn & 2.34 & 2.35 & 2.36 \\
\hline Mineral-vitamin $\operatorname{mix}^{5}$ & 1.61 & 1.61 & 1.61 \\
\hline $\mathrm{NPN}^{6}$ & 0.39 & 0.39 & 0.39 \\
\hline Sodium bicarbonate & 3.21 & & \\
\hline Sodium acetate & & 2.87 & \\
\hline Calcium butyrate & & & 2.47 \\
\hline \multicolumn{4}{|c|}{ Nutrient composition, $\%$ of $\mathrm{DM} \pm \mathrm{SD}$} \\
\hline $\mathrm{CP}$ & $14.6 \pm 0.7$ & $14.6 \pm 0.7$ & $14.7 \pm 0.7$ \\
\hline $\mathrm{NDF}$ & $30.7 \pm 0.7$ & $30.8 \pm 0.7$ & $30.9 \pm 0.7$ \\
\hline $\mathrm{ADF}$ & $12.5 \pm 0.1$ & $12.5 \pm 0.1$ & $12.6 \pm 0.1$ \\
\hline Starch & $18.7 \pm 0.9$ & $18.7 \pm 0.9$ & $18.8 \pm 0.9$ \\
\hline Fatty acids (FA) & $4.31 \pm 0.6$ & $4.33 \pm 0.6$ & $4.35 \pm 0.6$ \\
\hline \multicolumn{4}{|l|}{$\mathrm{FA}, \%$ of $\mathrm{FA}$} \\
\hline C16:0 & $7.40 \pm 1$ & $7.43 \pm 1$ & $7.46 \pm 1$ \\
\hline C18:0 & $2.87 \pm 0.2$ & $2.88 \pm 0.2$ & $2.89 \pm 0.2$ \\
\hline C18:1n-9 & $10.2 \pm 1.5$ & $10.2 \pm 1.5$ & $10.2 \pm 1.5$ \\
\hline C18:2n-6 & $18.8 \pm 2.6$ & $18.8 \pm 2.6$ & $18.9 \pm 2.6$ \\
\hline C18:3n-3 & $2.46 \pm 0.09$ & $2.47 \pm 0.09$ & $2.48 \pm 0.09$ \\
\hline DCAD, $\mathrm{mEq} / 100 \mathrm{~g}$ & $5.22 \pm 0.17$ & $4.78 \pm 0.11$ & $1.24 \pm 0.002$ \\
\hline
\end{tabular}

${ }^{1}$ Cows were fed the same basal TMR diet $\left(1.67 \mathrm{Mcal} / \mathrm{kg}\right.$ of $\left.\mathrm{NE}_{\mathrm{L}}\right)$, and treatments were mixed into the basal diet.

${ }^{2}$ Treatments were sodium bicarbonate control (3.2\% of diet DM), sodium acetate at $2.9 \%$ of diet DM (targeting $10 \mathrm{~mol}$ of acetate/d; NaAc; food-grade anhydrous sodium acetate, Kemin Industries Inc., Des Moines, IA), and calcium butyrate at $2.5 \%$ of diet $\mathrm{DM}(\mathrm{CaBu}$; Kemin Industries Inc.) to provide an equivalent carbon mass as the $\mathrm{NaAc}$ treatment.

${ }^{3}$ Acetate contained in $\mathrm{NaAc}$ provided 2.09 Mcal of $\mathrm{NE}_{\mathrm{L}} / \mathrm{d}$.

${ }^{4}$ Butyrate contained in $\mathrm{CaBu}$ provided $2.65 \mathrm{Mcal}$ of $\mathrm{NE}_{\mathrm{L}} / \mathrm{d}$.

${ }^{5}$ Contained (\%, as-fed basis): 45.8 dried corn distillers grains with solubles; 35.8 limestone (38\% Ca); 8.3 magnesium oxide $(54 \% \mathrm{Mg}) ; 6.4$ salt; 1.73 vitamin ADE premix; 1.09 selenium premix (0.06\% selenium); and 0.88 trace mineral mix.

${ }^{6}$ Nonprotein nitrogen fed as a slow-release urea (259\% CP, DM basis; Optigen, Alltech Inc., Lexington, KY).

\section{Statistical Analysis}

Data were analyzed as repeated measures in SAS (version 9.3, SAS Institute Inc., Cary, NC) and the model included the random effect of cow, period, and treatment sequence and the fixed effects of a covariate (observed value for variable of interest on the day before treatment feeding), treatment, day of treatment, and their interaction. Subject was cow by period and the CS covariance structure was used. Denominator degrees of freedom were adjusted with the Kenwood Rogers method. Data points with Studentized residuals outside of \pm 3.5 were considered outliers and excluded from analysis. A protected least significant difference separation was used within each time point to compare treatment means when the treatment or treatment by time interaction was significant. Differences were declared significant at $P \leq 0.05$ and tendencies at $0.05<$ $P \leq 0.10$.

\section{RESULTS AND DISCUSSION}

A treatment by time interaction was observed for DMI, as NaAc increased DMI over $2.5 \mathrm{~kg} / \mathrm{d}$ and $\mathrm{CaBu}$ decreased DMI over $2.6 \mathrm{~kg} / \mathrm{d}$ during treatment periods, compared with control $(P<0.05$; Figure 1A). Reduced DMI in the $\mathrm{CaBu}$ treatment may have been due to palatability issues (Huhtanen et al., 1993); however, 

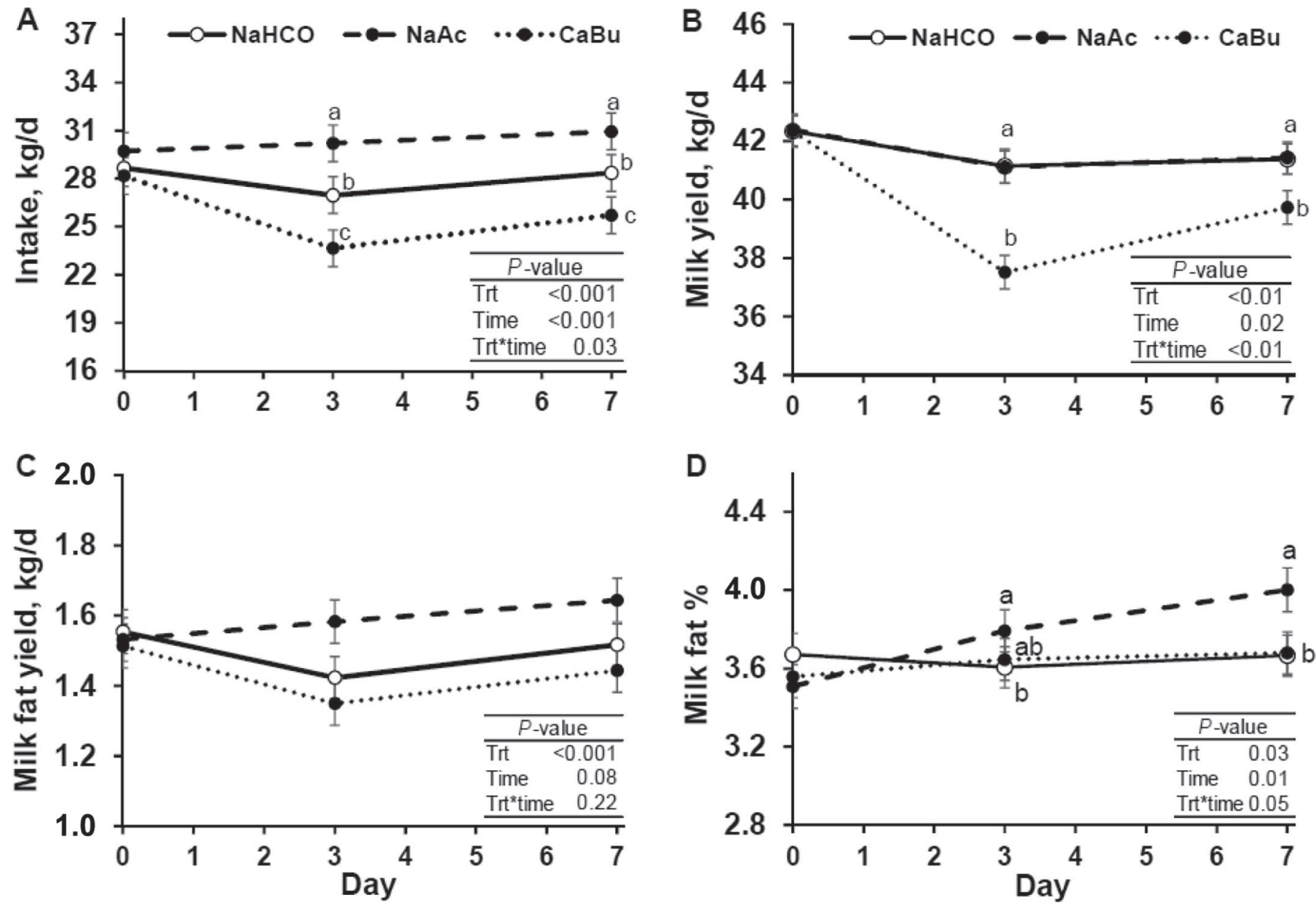

Figure 1. Time course of DMI (panel A), milk yield (panel B), milk fat yield (panel C), and milk fat concentration (panel D) of cows fed sodium bicarbonate at $3.2 \%$ of diet DM (control; NaHCO), sodium acetate at $2.9 \%$ of diet DM (NaAc), and calcium butyrate at $2.5 \%$ of diet $\mathrm{DM}(\mathrm{CaBu}$; equal carbon mass of NaAc; $\mathrm{n}=12$ per treatment). Least squares means and $\mathrm{SE}$ are shown, and means that do not share a letter $(\mathrm{a}-\mathrm{c})$ differ within time point $(P<0.05)$. Trt $=$ treatment.

in previous research where butyrate was incorporated into pelleted concentrates as calcium salts (Balch et al., $1967)$ or infused ruminally as sodium salts ( $\sim 700 \mathrm{~g}$ of butyrate/d; Herrick et al., 2018), DMI was not affected. Providing butyric and acetic acid as diluted acids has reduced feed intake, presumably due to stimulation of satiety signals through chemoreceptors in the rumen wall, liver, or portal system (Rook et al., 1965; Simkins et al., 1965).

A treatment by time interaction was observed for milk yield, as NaAc had no effect on milk yield, but $\mathrm{CaBu}$ decreased milk yield by over $4 \%(-1.65 \mathrm{~kg} / \mathrm{d})$ during the treatment period compared with control (treatment by time interaction, $P<0.01$; Figure 1B). The decrease in milk yield with $\mathrm{CaBu}$ is in agreement with the reduced DMI reported above.

Milk fat yield was increased $90 \mathrm{~g} / \mathrm{d}$ by $\mathrm{NaAc}$ and decreased $60 \mathrm{~g} / \mathrm{d}$ by $\mathrm{CaBu}$ compared with control $(P<$
0.05; Figure 1C). A similar amount of sodium acetate (10 mol/d) increased milk fat yield $217 \mathrm{~g} / \mathrm{d}$ compared with a sodium chloride control when ruminally infused over $22 \mathrm{~h} / \mathrm{d}$ (Urrutia and Harvatine, 2017b). The larger response with continuous infusion may be due to increased acetate availability over the entire day, while inclusion in TMR provides boluses with each meal. A treatment by time interaction was observed for milk fat concentration as NaAc increased milk fat concentration on $\mathrm{d} 3$ and 7 compared with control $(0.20$ and 0.34 percentage points, respectively; interaction, $P=0.05$; Figure 1D). Previous studies have shown increased milk fat concentration with rumen infusion of butyrate (Rook et al., 1965; Huhtanen et al., 1993), with only small nonsignificant reductions in DMI when providing high doses of butyric acid (Rook et al., 1965). As DMI was reduced with $\mathrm{CaBu}$ in the present experiment, other precursors for fat synthesis such as acetate are expected 
to have also decreased and may have limited a positive effect of butyrate on milk fat synthesis.

Milk protein concentration did not differ between $\mathrm{NaAc}$ and control, but was decreased by $\mathrm{CaBu}$ compared with control $(P<0.05)$. Early and more recent research has not shown a consistent effect of increasing butyrate supply on milk protein content. For example, Huhtanen et al. (1993) when providing rumen infusion of increasing concentrations of butyrate (from 0 to $600 \mathrm{~g} / \mathrm{d}$ ) in isoenergetic mixture of VFA, observed a positive linear response of milk protein content (from $3.27 \%$ to $3.46 \%$ milk protein), whereas Rook and Balch (1961) observed no effect of $880 \mathrm{~g} / \mathrm{d}$ of butyrate infused ruminally on milk protein content. It is likely that milk protein content was reduced in $\mathrm{CaBu}$ due to reduced feed intake, as feed restriction results in decreased milk and milk component yield and concentration (Wilson et al., 1967). A treatment by time interaction was observed for milk protein yield, as NaAc increased milk protein yield by $79 \mathrm{~g} / \mathrm{d}$ on $\mathrm{d} 3$ of treatments, whereas $\mathrm{CaBu}$ reduced milk protein yield over $100 \mathrm{~g} / \mathrm{d}$ on d 3 and 7 of treatments, compared with control (Figure 2 ). Responses in milk protein yield were driven by increased milk yield for $\mathrm{NaAc}$, but were a combination of reduced milk protein concentration and milk yield in $\mathrm{CaBu}$. In previous research, milk protein concentration and yield were not affected by short (Urrutia and Harvatine, 2017a,b) or long-term (Sheperd and Combs, 1998) ruminal infusion of acetate.

There were treatment by time interactions for yield of de novo and mixed origin FA $(P=0.09$ and $P=$ 0.02 , respectively; Figure 3$)$. De novo FA were increased $50 \mathrm{~g} / \mathrm{d}$ by $\mathrm{NaAc}$ on $\mathrm{d} 3(P<0.05)$ compared with control. Calcium butyrate decreased de novo FA by 12 $\mathrm{g} / \mathrm{d}$ on $\mathrm{d} 7$, compared with control. Sodium acetate also increased mixed source FA by over $50 \mathrm{~g} / \mathrm{d}$ during the entire treatment period (d 3 to 7 ), compared with control. During ruminal infusion of neutralized acetate, Urrutia and Harvatine (2017b) reported increased yield of de novo $(57 \mathrm{~g} / \mathrm{d})$ and mixed origin FA $(87 \mathrm{~g} / \mathrm{d})$ in response to continuous rumen infusions of sodium acetate $(10 \mathrm{~mol} / \mathrm{d})$, in a similar magnitude to the present experiment.

Treatment by time interactions were detected for the concentration of all FA grouped by source (de novo, mixed, and preformed) and for trans-10 C18:1 (all $P$ $<0.01$; Supplemental Figure S1; https://doi.org/10 .3168/jds.2018-16024). The concentration of de novo synthetized FA $(<16 \mathrm{C} \mathrm{FA}$; g/100 g) were increased by $\mathrm{NaAc}$ on d 3 compared with control and by $\mathrm{CaBu}$ on $\mathrm{d} 7$ compared with control. Concentration of mixed source FA (16 C FA) were increased by $\mathrm{NaAc}$ on $\mathrm{d} 3$ and 7 and reduced by $\mathrm{CaBu}$ on $\mathrm{d} 3$, compared with control. Concentration of preformed FA ( $>16$ C FA) were reduced by $\mathrm{NaAc}$ on $\mathrm{d} 3$ and 7 , and increased by $\mathrm{CaBu}$ on $\mathrm{d} 3$ compared with control. The $\mathrm{CaBu}$ increased concentration of milk trans-10 $\mathrm{C} 18: 1$ on $\mathrm{d}$ 3 and 7 of treatment (treatment by time interaction, $P<0.01$; Supplemental Figure S1; https://doi.org/10 $.3168 /$ jds.2018-16024) indicating a shift in rumen biohydrogenation toward alternate pathways that result in biohydrogenation-induced milk fat depression.

Analysis of individual FA identified some FA specific responses (Table 2). No treatment or treatment by time interactions effects were observed for C4:0, C6:0, and C8:0. NaAc decreased milk concentration of C17:0, trans-11 C18:1, cis-9, trans-11 CLA, and total odd- and
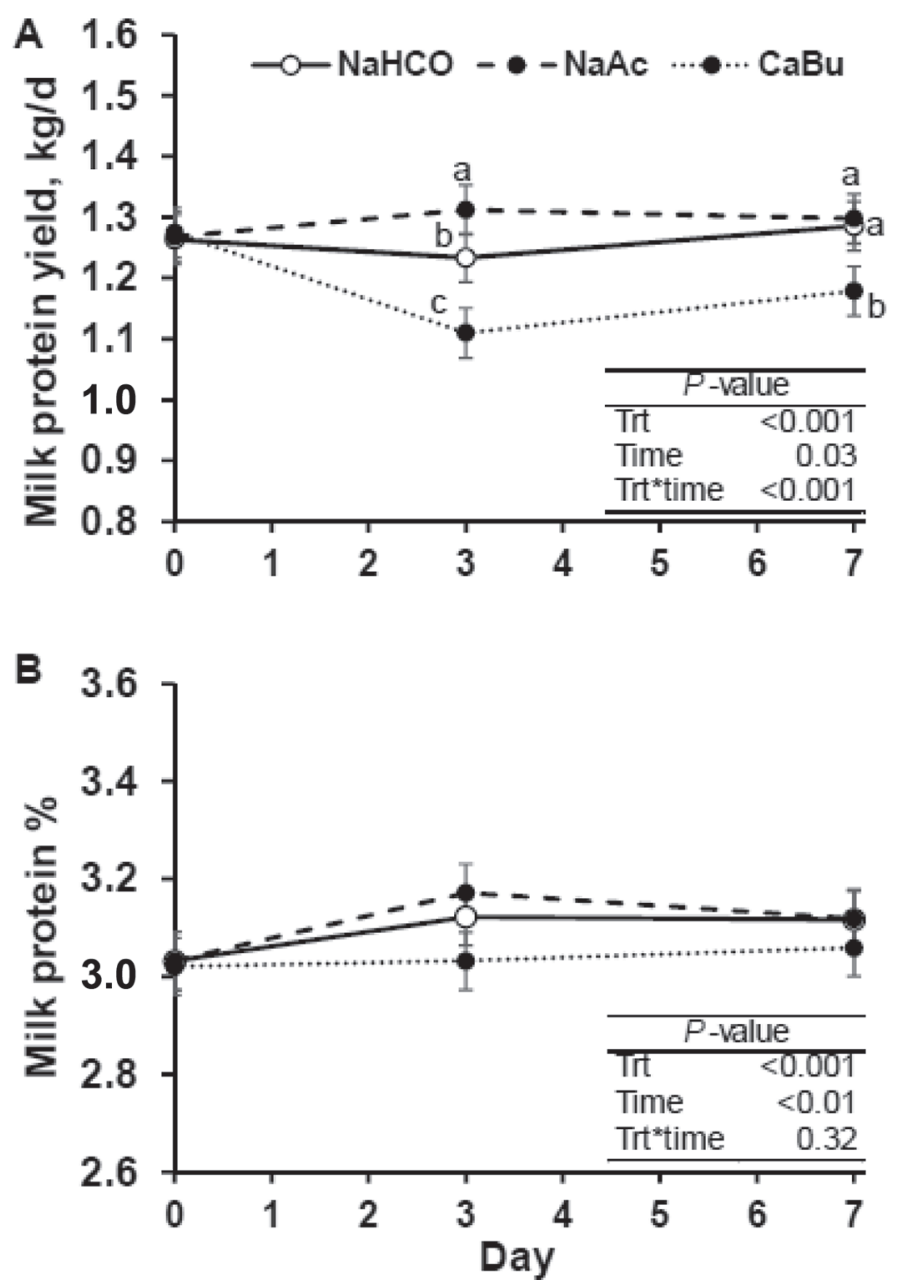

Figure 2. Time course of milk protein yield (panel A) and concentration (panel B) of cows fed sodium bicarbonate at $3.2 \%$ of diet DM (control; $\mathrm{NaHCO}$ ), sodium acetate at $2.9 \%$ of diet $\mathrm{DM}(\mathrm{NaAc})$, and calcium butyrate at $2.5 \%$ of diet $\mathrm{DM}(\mathrm{CaBu}$; equal carbon mass of NaAc; $\mathrm{n}=12$ per treatment). Least squares means and $\mathrm{SE}$ are shown, and means that do not share a letter $(\mathrm{a}-\mathrm{c})$ differ within time point $(P$ $<0.05)$. Trt $=$ treatment. 
branched-chain FA compared with control (all $P<0.05$, Table 2). The $\mathrm{CaBu}$ increased concentration of $\mathrm{C} 17: 0$ and C17:1, compared with control (both $P<0.05$ ). Several treatment by time interactions were detected (Supplemental Table S1; https://doi.org/10.3168/jds .2018-16024). Importantly, NaAc increased concentration of palmitic acid (C16:0) and reduced concentration of iso C14:0, trans-9 C18:1, C18:2 n-6, and C18:3 n-3 in milk fat on $\mathrm{d} 3$ and 7 of treatments, compared with control $(P<0.05)$. Also, NaAc increased concentration of C10:0, C12:0, and C14:0, and reduced concentration of anteiso C15:0, anteiso C17:0, and cis-9 C18:1 in milk fat on d 3, compared with control (all $P<0.05$ ). Feeding $\mathrm{CaBu}$ increased milk concentration of iso C15:0, iso $\mathrm{C} 17: 0, \mathrm{C} 18: 0$ on $\mathrm{d} 3$, and $\mathrm{C} 10: 0, \mathrm{C} 12: 0$, anteiso C13:0, and C14:0 on d 7, compared with control (all $P<0.05$ ). Also, $\mathrm{CaBu}$ reduced concentration of milk $\mathrm{C} 14: 0$, iso C16:0, and $\mathrm{C} 16: 0$ on $\mathrm{d} 3$ and anteiso C15:0, anteiso C17:0, and C18:0 on d 7, compared with control (all $P<0.05$ ). The $\mathrm{CaBu}$ increased concentration of trans $-918: 1$ on $\mathrm{d} 3$ and 7 and reduced concentration of iso C14:0 on d 3 and 7, compared with control $(P<$ 0.05). Overall, NaAc increased milk fat synthesis primarily through an increase in synthesis of de novo and mixed FA (C10:0, C12:0; C:14; C16:0), whereas CaBu increased synthesis of $\mathrm{C} 10: 0$ and $\mathrm{C} 12: 0$ and modified FA of microbial origin, indicating a shift in rumen fermentation pattern (Vlaeminck et al., 2006).

Treatment by time interactions were detected for plasma NEFA and BUN (Figure 4A and 4B). The $\mathrm{CaBu}$ reduced plasma NEFA by $18 \%$ and increased BUN by $12 \%$ at $1700 \mathrm{~h}$ compared with control (both $P<0.05)$. Also, both NaAc and CaBu increased BUN by over $24 \%$ at $0500 \mathrm{~h}$ compared with control $(P<$ 0.05). Reduced plasma NEFA in CaBu may result from a BHB-mediated lipolysis inhibition through activation of adipose nutrient sensing receptors such as the hydroxycarboxylic acid receptor 2 (Metz and Bergh, 1972;
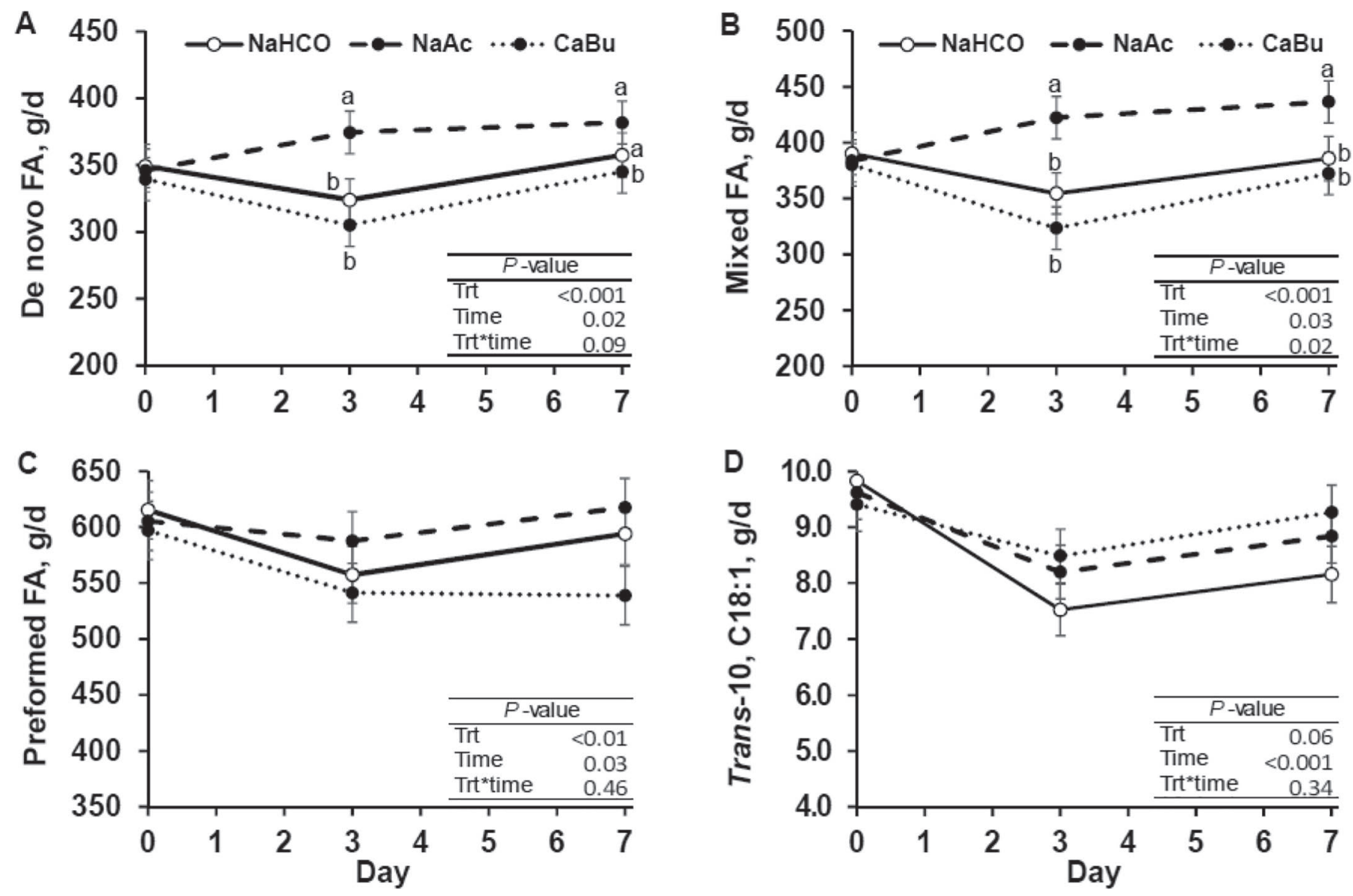

Figure 3. Time course of milk fatty acid (FA) yield of de novo ( $<16$ carbons; panel A), mixed source (16 carbons; panel B), preformed origin (>16 carbons; panel C), and trans-10, C18:1 (panel D) of cows fed sodium bicarbonate at 3.2\% of diet DM (control; NaHCO), sodium acetate at $2.9 \%$ of diet DM (NaAc), and calcium butyrate at $2.5 \%$ of diet DM (CaBu; equal carbon mass of NaAc; $\mathrm{n}=12$ per treatment). Least squares means and SE are shown, and means that do not share a letter $(\mathrm{a}, \mathrm{b})$ differ within time point $(P<0.05)$. Trt $=$ treatment. 
Mielenz, 2017). However, recent studies have not shown reductions in plasma NEFA in response to rumen infusion of butyrate (Herrick et al., 2018) or to high plasma BHB resulting from rumen acetate infusion (Urrutia and Harvatine, 2017b). Blood urea nitrogen is an indicator of efficiency of protein utilization and is related to energy balance and plasma NEFA (Broderick and Clayton, 1997; Rastani et al., 2006). Elevated BUN observed in $\mathrm{CaBu}$ may indicate inefficient dietary protein utilization or increased body protein mobilization and catabolism due to reduced feed intake.

Treatment affected plasma glucose and BHB (Figure 4). Plasma BHB concentration was 539, 650, and 853 $\mathrm{mg} / \mathrm{dL}$ in control, $\mathrm{NaAc}$, and $\mathrm{CaBu}$ treatments, respectively $(\mathrm{SE}=125$; Figure $4 \mathrm{C})$. The NaAc did not affect $\mathrm{BHB}$, whereas $\mathrm{CaBu}$ increased $\mathrm{BHB}$ by $58 \%$, compared with control $(P<0.05)$. In previous studies (Urrutia and Harvatine, 2017a,b), continuous acetate infusions resulted in increased plasma BHB compared with sodium chloride control; however, in the present study, feeding sodium acetate did not affect plasma BHB compared with a sodium bicarbonate control. Possible reasons may include a synchronized availability of rumen acetate and butyrate (made from acetate) with rumen wall energy demand after feeding in the present study, reducing transfer to blood circulation. Feeding butyrate $(\mathrm{CaBu})$ in the current experiment resulted in a similar increase in plasma BHB compared with previous continuous ruminal acetate infusions (Urrutia and Harvatine, 2017b). This agrees with previous findings, as rumen butyrate, once absorbed is rapidly metabolized to BHB by rumen epithelial cells (Storry and Rook, 1965b). In the current study, both NaAc and $\mathrm{CaBu}$ reduced plasma glucose concentration by $\sim 10 \%$ compared with control $(P<0.05$; Figure 4D). Early reports have shown a role for butyrate in the regulation of glucose metabolism (Storry and Rook, 1965a), supported by in vitro studies where butyrate inhibits liver uptake of propionate (Demigné et al., 1986). Recently, Herrick et al. (2018) reported a 10\% reduction

Table 2. Effect of feeding sodium acetate (NaAc) and an equal carbon mass of calcium butyrate $(\mathrm{CaBu})$ on milk fatty acid (FA) composition

\begin{tabular}{|c|c|c|c|c|c|c|c|}
\hline FA, g/100 g & \multicolumn{3}{|c|}{ Treatment $^{1}$} & $\mathrm{SE}$ & \multicolumn{3}{|c|}{$P$-value } \\
\hline C6:0 & 2.17 & 2.17 & 2.21 & 0.027 & 0.31 & $<0.001$ & 0.82 \\
\hline $\mathrm{C} 8: 0$ & 1.18 & 1.19 & 1.20 & 0.022 & 0.37 & $<0.001$ & 0.34 \\
\hline C10:0 & 2.58 & 2.64 & 2.62 & 0.057 & 0.34 & $<0.001$ & 0.05 \\
\hline C11:0 & 0.042 & 0.042 & 0.042 & 0.002 & 0.66 & $<0.001$ & 0.85 \\
\hline anteiso $\mathrm{C} 13: 0$ & 0.056 & 0.056 & 0.059 & 0.001 & 0.16 & $<0.001$ & 0.02 \\
\hline iso $\mathrm{C} 14: 0$ & 0.102 & 0.091 & 0.082 & 0.004 & $<0.001$ & $<0.001$ & 0.06 \\
\hline C14:0 & 10.1 & 10.4 & 10.1 & 0.12 & $<0.01$ & 0.12 & $<0.001$ \\
\hline iso $\mathrm{C} 15: 0$ & 0.199 & 0.201 & 0.202 & 0.003 & 0.39 & $<0.001$ & 0.03 \\
\hline anteiso C15:0 & 0.36 & 0.35 & 0.35 & 0.004 & 0.04 & 0.35 & 0.04 \\
\hline C15:0 & 0.85 & 0.83 & 0.85 & 0.012 & 0.22 & $<0.001$ & 0.75 \\
\hline iso $\mathrm{C} 16: 0$ & 0.22 & 0.22 & 0.19 & 0.010 & 0.04 & $<0.001$ & 0.01 \\
\hline C18:0 & 12.7 & 13.0 & 12.9 & 0.17 & 0.42 & $<0.01$ & $<0.001$ \\
\hline trans-9 C18:1 & 0.33 & 0.32 & 0.34 & 0.011 & $<0.001$ & 0.18 & $<0.001$ \\
\hline trans-10 C18:1 & 0.59 & 0.59 & 0.66 & 0.020 & $<0.001$ & 0.04 & $<0.01$ \\
\hline trans-11 C18:1 & $1.27^{\mathrm{a}}$ & $1.2^{\mathrm{b}}$ & $1.27^{\mathrm{a}}$ & 0.035 & 0.01 & $<0.001$ & 0.25 \\
\hline cis-9 C18:1 & 19.5 & 18.8 & 19.4 & 0.56 & $<0.01$ & $<0.001$ & $<0.001$ \\
\hline $\mathrm{C} 18: 2 \mathrm{n}-6$ & 3.12 & 2.95 & 3.17 & 0.097 & $<0.001$ & 0.06 & $<0.01$ \\
\hline C18:3n-3 & 0.47 & 0.44 & 0.47 & 0.017 & $<0.01$ & 0.25 & 0.01 \\
\hline cis-9,trans C18:2 & $0.54^{\mathrm{a}}$ & $0.51^{\mathrm{b}}$ & $0.53^{\mathrm{a}}$ & 0.014 & 0.01 & $<0.001$ & 0.12 \\
\hline$\Sigma \mathrm{OBCFA}^{3}$ & $3.05^{\mathrm{a}}$ & $2.96^{\mathrm{b}}$ & $3.03^{\mathrm{a}}$ & 0.026 & $<0.001$ & $<0.001$ & 0.32 \\
\hline
\end{tabular}

${ }^{\mathrm{a}-\mathrm{c}}$ Least squares means that do not share a superscript are significantly different $(P<0.05)$.

${ }^{1}$ Treatments were on a DM basis: $3.2 \% \mathrm{NaHCO}_{3}$ (control), $2.9 \% \mathrm{NaAc}$, and $2.5 \% \mathrm{CaBu}$ (carbon equivalent to acetate treatment), $\mathrm{n}=12 \mathrm{per}$ treatment.

${ }^{2}$ Main effects of treatment (Trt) when a Trt by time interaction was detected are described in the text and shown in Supplemental Table S1 (https://doi.org/10.3168/jds.2018-16024).

${ }^{3}$ Odd- and branched-chain FA. 

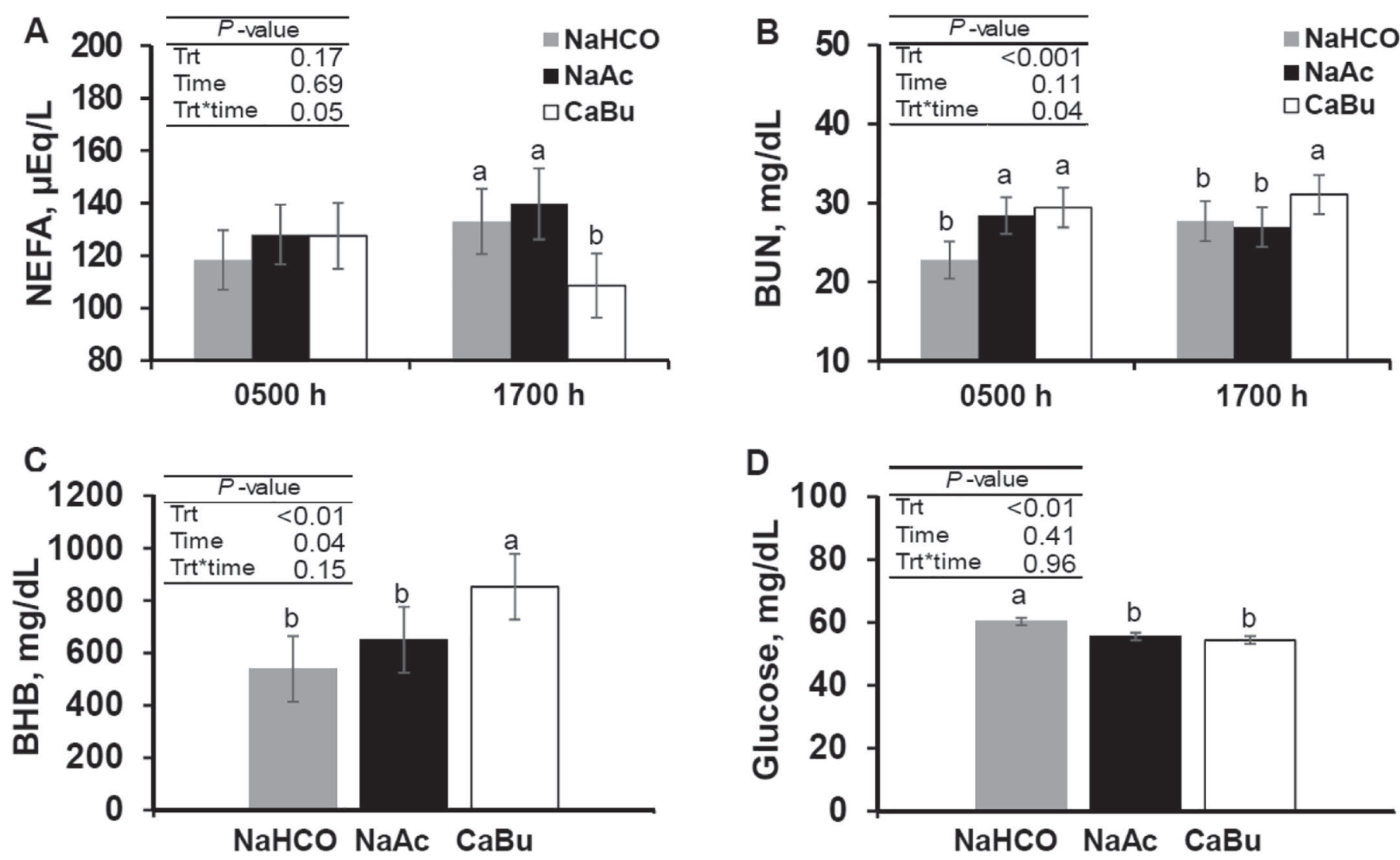

Figure 4. Effect of feeding sodium bicarbonate at 3.2\% of diet DM (control; NaHCO), sodium acetate at 2.9\% of diet DM (NaAc), and calcium butyrate at $2.5 \%$ of diet DM (CaBu; equal carbon mass of NaAc) on plasma nonesterified fatty acids (NEFA; panel A), BUN (panel B), plasma BHB (panel C), and plasma glucose (panel D; $\mathrm{n}=12$ per treatment). Least squares means and SE are shown, and means that do not share a letter $(\mathrm{a}, \mathrm{b})$ differ within time point $(P<0.05)$. Trt $=$ treatment.

in plasma glucose when providing $\sim 700 \mathrm{~g} / \mathrm{d}$ of butyrate as a continuous ruminal infusion. Although previous studies have not shown reductions in plasma glucose in response to acetate infusion (Storry and Rook, 1965a; Sheperd and Combs, 1998; Urrutia and Harvatine, 2017a,b), it is possible that increased milk fat synthesis in NaAc resulted in an increase in glucose requirement for NADPH synthesis in the mammary gland.

Continuous sodium acetate infusions resulted in a linear increase in rumen $\mathrm{pH}$ compared with a sodium chloride control (Urrutia and Harvatine, 2017b), as sodium acetate infused at a $\mathrm{pH}$ of 6.0 provided buffering capacity to the rumen. The use of a sodium chloride control did not allow control for buffering capacity and for DCAD. Interestingly, DCAD has been reported to increase milk fat yield and concentration $[0.1 \%$ and $36 \mathrm{~g} / \mathrm{d}$ for every $100 \mathrm{mEq} / \mathrm{kg}$ increase in DCAD, respectively; Iwaniuk and Erdman (2015)] presumably through improved rumen buffering capacity, although the mechanism has not been demonstrated. Improved buffering capacity may result in a shift of rumen fermentation pathways toward reduced formation of alternate biohydrogenation intermediates that induce milk fat depression such as trans-10 C18:1 and trans10,cis-12 C18:2 (Harvatine et al., 2009), and therefore, an apparent increase in milk fat synthesis.

In the present experiment, a sodium bicarbonate treatment was used to provide a DCAD and buffering capacity control to sodium acetate. We observed no treatment or treatment by time interactions for $\mathrm{NaAc}$ on milk trans-10 C18:1, compared with control (Figure 3 and Supplemental Figure S1; https://doi.org/10 .3168/jds.2018-16024), and trans-10,cis-12 C18:2 was not detected in any sample; therefore, we attribute the milk fat yield and concentration response observed in the current experiment to acetate supply and not a rumen buffering capacity or DCAD effect. Yet, the provision of sodium acetate as a feed supplement would provide an additional benefit to the increase in milk fat synthesis, as it would improve rumen buffering capacity and therefore rumen health, especially when feeding more highly fermentable diets and during the high 
intake period of the day after delivery of fresh feed and during the afternoon when rumen $\mathrm{pH}$ is lowest (Salfer et al., 2018).

Several mechanisms may be involved in the increased milk fat synthesis observed with acetate supplementation, including simply an increase in substrate supply for milk fat synthesis or modification of metabolism as a bioactive nutrient. Molecular mechanisms exist for acetate to potentially modify metabolic signaling and regulation of gene expression (discussed by Urrutia and Harvatine, 2017b), but have not been well investigated in the cow. Feeding sodium acetate is expected to increase acetate supply more during the high intake period of the day (feeding to midnight). To determine if treatment effects differed at the morning and afternoon milking, milking time $(\mathrm{AM} / \mathrm{PM})$ and its interaction with treatment and experimental day were tested but were not significant (data not shown). This may be due to the timing of milking relative to the high intake period of the day and may require increased milking frequency to observe a temporal effect on milk fat yield.

\section{CONCLUSIONS}

In conclusion, milk fat yield and concentration can be increased by dietary supplementation of sodium acetate, and not calcium butyrate at the level investigated. Increased milk fat synthesis observed during acetate feeding may be due to either a greater substrate supply allowing greater synthesis of de novo and mixed FA, modification of metabolism by acetate, or a combination of these. Inclusion of sodium acetate into dairy cow diets will depend on the cost of a commercial supplement and market price for milk fat.

\section{ACKNOWLEDGMENTS}

The authors gratefully acknowledge the technical assistance of undergraduate and graduate students of the Harvatine laboratory, Penn State University, University Park. Gratitude is also expressed to the staff at the Pennsylvania State University Dairy Cattle Research and Education Center. Sodium acetate and calcium butyrate were graciously donated by Kemin Industries Inc. (Des Moines, IA). This project was partially supported by Penn State University including USDA National Institute of Food and Agriculture Federal Appropriations under Project number PEN04539 and accession number 1000803.

\section{REFERENCES}

Balch, C., W. Broster, V. Johnson, C. Line, J. Rook, J. Sutton, and V. J. Tuck. 1967. The effect on milk yield and composition of adding the calcium salts of acetic, propionic, butyric and lactic acids to the diets of dairy cows. J. Dairy Res. 34:199-206.

Baldwin, R., and N. Smith. 1971. Intermediary aspects and tissue interactions of ruminant fat metabolism. J. Dairy Sci. 54:583-595.

Ballou, M. A., R. C. Gomes, S. O. Juchem, and E. J. DePeters. 2009. Effects of dietary supplemental fish oil during the peripartum period on blood metabolites and hepatic fatty acid compositions and total triacylglycerol concentrations of multiparous Holstein cows. J. Dairy Sci. 92:657-669.

Bauman, D. E., R. E. Brown, and C. L. Davis. 1970. Pathways of fatty acid synthesis and reducing equivalent generation in mammary gland of rat, sow, and cow. Arch. Biochem. Biophys. 140:237-244.

Bergman, E. N. 1990. Energy contributions of volatile fatty acids from the gastrointestinal tract in various species. Physiol. Rev. 70:567-590.

Broderick, G. A., and M. K. Clayton. 1997. A statistical evaluation of animal and nutritional factors influencing concentrations of milk urea nitrogen. J. Dairy Sci. 80:2964-2971.

Demigné, C., C. Yacoub, C. Rémésy, and P. Fafournoux. 1986. Propionate and butyrate metabolism in rat or sheep hepatocytes. Biochimica et Biophysica Acta 875:535-542.

Harvatine, K. J., Y. R. Boisclair, and D. E. Bauman. 2009. Recent advances in the regulation of milk fat synthesis. Animal 3:40-54.

Herrick, K. J., A. R. Hippen, K. F. Kalscheur, D. J. Schingoethe, S. D. Ranathunga, J. L. Anderson, S. C. Moreland, and J. E. van Eys. 2018. Infusion of butyrate affects plasma glucose, butyrate, and beta-hydroxybutyrate but not plasma insulin in lactating dairy cows. J. Dairy Sci.101:3524-3536.

Huhtanen, P., H. Miettinen, and M. Ylinen. 1993. Effect of increasing ruminal butyrate on milk yield and blood constituents in dairy cows fed a grass silage-based diet. J. Dairy Sci. 76:1114-1124.

Ingle, D. L., D. E. Bauman, R. W. Mellenberger, and D. E. Johnson. 1973. Lipogenesis in the ruminant: Effect of fasting and refeeding on fatty acid synthesis and enzymatic activity of sheep adipose tissue. J. Nutr. 103:1479-1488.

Iwaniuk, M. E., and R. Erdman. 2015. Intake, milk production, ruminal, and feed efficiency responses to dietary cation-anion difference by lactating dairy cows. J. Dairy Sci. 98:8973-8985.

Maxin, G., H. Rulquin, and F. Glasser. 2011. Response of milk fat concentration and yield to nutrient supply in dairy cows. Animal 5:1299-1310.

Metz, S. H. M., and S. G. d. Bergh. 1972. Effects of volatile fatty acids, ketone bodies, glucose, and insulin on lipolysis in bovine adipose tissue. FEBS Lett. 21:203-206.

Mielenz, M. 2017. Invited review: Nutrient-sensing receptors for free fatty acids and hydroxycarboxylic acids in farm animals. Animal 11:1008-1016.

Palmquist, D., A. D. Beaulieu, and D. Barbano. 1993. Feed and animal factors influencing milk fat composition. J. Dairy Sci. 76:17531771.

Palmquist, D., C. Davis, R. Brown, and D. Sachan. 1969. Availability and metabolism of various substrates in ruminants. V. Entry rate into the body and incorporation into milk fat of $\mathrm{D}(-)$ 3-hydroxybutyrate. J. Dairy Sci. 52:633-638.

Raabo, B. E., and T. Terkildsen. 1960. On the enzymatic determination of blood glucose. Scand. J. Clin. Lab. Invest. 12:402-407.

Rastani, R. R., N. E. Lobos, M. J. Aguerre, R. R. Grummer, and M. A. Wattiaux. 2006. Relationships between blood urea nitrogen and energy balance or measures of tissue mobilization in Holstein cows during the periparturient period. Prof. Anim. Sci. 22:382-385.

Rico, D., Y. Ying, and K. Harvatine. 2014. Effect of a high-palmitic acid fat supplement on milk production and apparent total-tract digestibility in high-and low-milk yield dairy cows. J. Dairy Sci. 97:3739-3751.

Rook, J. A. F., and C. C. Balch. 1961. The effects of intraruminal infusions of acetic, propionic and butyric acids on the yield and composition of the milk of the cow. Br. J. Nutr. 15:361-369.

Rook, J. A. F., C. C. Balch, and V. W. Johnson. 1965. Further observations on the effects of intraruminal infusions of volatile fatty acids and of lactic acid on the yield and composition of the milk of the cow. Br. J. Nutr. 19:93-99. 
Salfer, I. J., M. C. Morelli, Y. Ying, M. S. Allen, and K. J. Harvatine. 2018. The effects of source and concentration of dietary fiber, starch, and fatty acids on the daily patterns of feed intake, rumination, and rumen pH in dairy cows. J. Dairy Sci. 101:10911-10921.

Sheperd, A., and D. Combs. 1998. Long-term effects of acetate and propionate on voluntary feed intake by midlactation cows. J. Dairy Sci. 81:2240-2250.

Simkins, K. L., J. W. Suttie, and B. R. Baumgardt. 1965. Regulation of food intake in ruminants. 4. Effect of acetate, propionate, butyrate, and glucose on voluntary food intake in dairy cattle. J. Dairy Sci. 48:1635-1642.

Smith, S. B. 1983. Contribution of the pentose cycle to lipogenesis in bovine adipose tissue. Arch. Biochem. Biophys. 221:46-56.

Storry, J., and J. Rook. 1965a. Effect in the cow of intraruminal infusions of volatile fatty acids and of lactic acid on the secretion of the component fatty acids of the milk fat and on the composition of blood. Biochem. J. 96:210-217.

Storry, J. E., and J. Rook. 1965b. Effects of intravenous infusions of acetate, $\beta$-hydroxybutyrate, triglyceride and other metabolites on the composition of the milk fat and blood in cows. Biochem. J. $97: 879-886$

Sutton, J. D., M. Dhanoa, S. Morant, J. France, D. Napper, and E. Schuller. 2003. Rates of production of acetate, propionate, and butyrate in the rumen of lactating dairy cows given normal and low-roughage diets. J. Dairy Sci. 86:3620-3633.

Urrutia, N., and K. J. Harvatine. 2017a. Effect of conjugated linoleic acid and acetate on milk fat synthesis and adipose lipogenesis in lactating dairy cows. J. Dairy Sci. 100:5792-5804.

Urrutia, N. L., and K. J. Harvatine. 2017b. Acetate dose-dependently stimulates milk fat synthesis in lactating dairy cows. J. Nutr. 147:763-769.

Vlaeminck, B., V. Fievez, S. Tamminga, R. J. Dewhurst, A. van Vuuren, D. De Brabander, and D. Demeyer. 2006. Milk odd- and branched-chain fatty acids in relation to the rumen fermentation pattern. J. Dairy Sci. 89:3954-3964.

Wilson, G. F., A. W. F. Davey, and R. M. Dolby. 1967. Milk composition as affected by intra-ruminal infusion of volatile fatty acids to cows on a restricted ration. N. Z. J. Agric. Res. 10:215-225. 